\title{
Methods alter interpretation of treatment impacts on winter- fat shrublands
}

\author{
ANN L. HILD AND DAVID B. WESTER
}

Authors are assistant professor, Department of Rangeland Ecology and Watershed Management, University of Wyoming, Laramie, Wyo. 82071, and associate professor, Department of Range, Wildlife and Fisheries Management, Texas Tech University, Lubbock, Tex. 79409. At the time of the research, Ms. Hild was a teaching assistant, Department of Range, Wildlife, and Fisheries Management, Texas Tech University, Lubbock, Tex.

\begin{abstract}
Monitoring shrubland vegetation change is important to rangeland assessment. Methods used to document shrubs vary with the intended use of information and the unit of observation. This study documents different interpretations of winterfat (Ceratoides lanata (Pursh.) J.T. Howell) response to defoliation, grazing history, and community position treatments from 1992 through 1994 when the interpretations were based upon 2 different methods of observation. In some cases, results from observations of individual winterfat plants differed from results that were based on unit-area observations. Individual plants did not reflect the same impacts of grazing history that were found from observing the collective response of plants in $11-\mathrm{m}^{2}$ plots. Although plant results reflect impacts on individuals, plot results can indicate impacts of shrub canopy on surrounding vegetation as well. Comparisons of studies using different means of observation may lead to conflicting interpretations unless these effects are recognized.
\end{abstract}

Key Words: winterfat, Ceratoides lanata, monitoring, defoliation, canopy volume, scale

Researchers studying mixed species assemblages have developed an extensive palette of plant measurements that are difficult to synthesize uniformly. Data from different techniques may contribute, in part, to disagreement on resource uses such as domestic livestock grazing of public lands and assessment of rangeland health. Emphasis on forage production in range research results in measurements of production values on a unit-area basis. In contrast, plant ecologists interested in vegetation change via competitive or environmental constraints may examine responses on an individual plant basis. Shrubland vegetation measurements commonly include canopy volume, canopy cover, and basal cover of shrubs and herbs. Canopy volume has been suggested as a measure of relative species dominance (Daubenmire 1968) and as 1 predictor of browse production ( Bonham 1989, Bryant 1979, Cook and Stubbendieck 1986, Heady et al. 1959). Problems monitoring shrubland vegetation have been noted by

Research was funded in part by National Rifle Association, Grants-In-Aid, GIA \#93-09 and GIA \#94-11. This is contribution T-9-757, College of Agricultural Sciences and Natural Resources, Texas Tech University, Lubbock, Tex.

Manuscript accepted 22 Mar. 1997.
Abstracto

El monitoréo de cambios de la vegetación de arbustos es importante para la evaluación de pastizales. Los métodos empleados para documentar estos cambiosdependerán del uso que se le de a la información y de la unidad de observación. Este estudio presenta diferentes interpretaciones de la respuesta de "winterfat" (Ceratoides lanata (Pursh.) J.T. Howell) a la defoliación, historia de pastoreo, y tratamientos de la posición de comunidades desde 1992 hasta 1994 cuando las interpretaciones se basaron en 2 métodos diferentes de observación. En algunos casos, diferentes resultados fueron detectados entre observaciones basadas en plantas individuales de "winterfat" $\mathrm{y}$ áreas unitarias. Plantas individuales no reflejaron el mismo impacto por historia de pastoreo que fue detectado al observar la respuesta colectiva de plantas en áreas de $11 \mathrm{~m}^{2}$. Aunque los resultados basados en una planta reflejan los impactos sobre individuos, los resultados de áreas unitarias también pueden mostrar los efectos del follaje de arbustos sobre la vegetación vecina. La comparación de estudios que usen diferentes medios de observación puedan crear interpretaciones conflictivas a menos que tales efectos sean reconocidos.

these and other authors (Canfield 1941, Jameson 1987, Morris et al. 1976, Taylor 1986, Zamora 1981).

Vegetation changes that are apparent at global or landscape perspectives may not be discerned in measures of individual plants even within the same vegetation areas. This discrepancy derives from several sources. Mathematical differences between unit area and individual plant measures can result from incorporating density into unit-area computations. Biological inferences from unit-area measures may have different application than inferences from observations of individual plants. It is important to recognize the inherent nature of results from different units of observation and to realize that these results may support potentially different interpretations. Conflicting results in current range literature may derive, at least partially, from different methods of observation. This study addresses some problems and perceptions associated with comparing shrublands by using unit-area and individual plant observations. 


\section{Materials and Methods}

From 1992 to 1994 a study of winterfat (Ceratoides lanata [Pursh.] J.T.Howell)-blue grama (Bouteloua gracilis [H.B.K.] Lag. ex. Steud.) communities was conducted to compare plant growth under 3 defoliation treatments, in positions interior or peripheral to winterfat stands, and in locations with different grazing histories. Data presented here involve a comparison of 2 methods of observation (unit-area and individual plant).

\section{Study Site}

The study was conducted at the National Rifle Association Whittington Center and adjacent grazed lands near Raton in northeastern Colfax County, New Mexico. Plots were on the southern boundary fence lines of the Whittington Center, which lie across several visually obvious winterfat shrubland communities on the ecotone between pinyon-juniper (Pinus edulis Engelm. and Juniperus spp.) and grasslands. Study sites were on convex portions of alluvial fans derived from shales of the adjoining escarpments, at elevations between 1920 and $1956 \mathrm{~m}$. Precipitation averages $38 \mathrm{~cm}$ in the lower elevations, and is greatest during the summer months (USDA 1982). Rainfall totals for the Raton radio station for the 3 years of the study show somewhat dricr conditions, especially in the spring months, in the 1993 field season. Soils are mapped as a Colmor-Vermejo-Litle association; winterfat stands occurred on Vermejo fine, mixed (calcareous), mesic Ustic Torriorthents (USDA 1982). These sites consist of deep to moderately deep, well drained clay loam and silty clay loams; slopes average 0 to $5 \%$. The potential plant community includes alkali sacaton (Sporobolus airoides Torr., 25\%; blue grama, 20\%; western wheatgrass (Pascopyron smithii [Rydb.] Love), 15\%; galleta (Hilaria jamesii [Torr.] Benth.), 15\%; sideouts grama (Bouteloua curtipendula [Michx.] Torr.), $10 \%$ and vine mesquite (Panicum obtusum H.B.K.), spike muhly (Muhlenbergia wrightii Vasey), and fourwing saltbush (Atriplex canescens [Pursh.] Nutt.), each 5\%. Other species include prickly pear (Opuntia spp.), buckwheat (Eriogonum spp.), squirrel tail (Sitanion hystrix [Nutt.] J.G. Smith), and broom snakeweed (Gutierrezia sarothrae [Pursh] Britt. and Rusby).

Domestic livestock have been excluded from the Whittington Center since 1973 after a long history of grazing. Adjacent properties are grazed by cattle from mid May to mid October. Wildlife presence includes elk (Cervus elaphus canadensis), mule dcer (Odocoileus hemionus), antelope (Antilocapra americana), bear (Ursus americanus), turkey (Meleagris gallopavo), and many non-game species. On the Whittington, winterfat communities are used primarily as fall browse by elk and deer; summer use of grasses is apparently minimal since elk and deer tend to move to higher, more protected pinyon-juniper and ponderosa pine communities as temperatures in grasslands and shrublands increase. While there is some use on the Whittington, forage availability seems high for current ungulate populations (yield was $900 \mathrm{~kg} / \mathrm{ha}$ in June 1993; potential annual production is $600-2,000 \mathrm{~kg} / \mathrm{ha}$, USDA 1982).

\section{Experimental Design and Plot Arrangement}

Three visually recognizable winterfat community stands were used. Each community is bisected by fences constructed prior to 1945, one side of which (adjacent lands) has received moderate cattle grazing before and since 1973; the other (Whittington) side of these fences has been protected from domestic grazing since 1973. Both sides received wildlife use. Thus, the 2 location treatments (Whittington-ungrazed and adjacent-grazed) represent different grazing histories since 1973.

"Interior" positions within each community were defined and visibly recognized as winterfat-dominated positions that were surrounded by similarly dominated areas and were not adjoining "peripheral" positions (Fig. 1). "Peripheral" position plots were placed on the boundary between a winterfat community and adjoining grass-dominated vegetation. Winterfat cover and density increased toward interior positions but decreased away from peripheral plots. Visualized as concentric areas, a peripheral area comprised the outer third; interior areas were located in the center, and peripheral and interior areas were separated by a transitional area comprising approximately one-third of the community. Each study plot placed in peripheral and interior positions covers an $11-\mathrm{m}^{2}$ area.

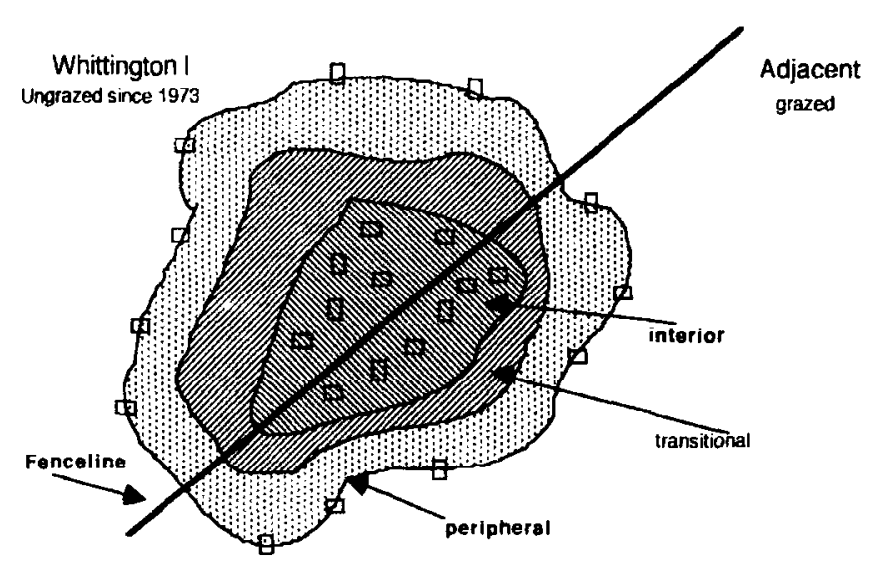

Fig. 1. Community locations and positions. (Each rectangle represents an $11 \mathrm{~m}^{2}$ plot.)

Within interior and peripheral positions of each community, six $4 \times 2.5$-m rectangular plots were established using chicken wire (2.5-cm mesh) and a 5-strand barbed wire fence to exclude both wild and domestic herbivores. Although large animals did not graze vegetation within the plots after fencing, some use by small mammals, especially mice (Peromyscus spp.) and kangaroo rats (Dippdomys spp.), was observed. Black-tailed jackrabbit (Lepus californicus) use, although not directly observed, may have occurred. Plots were placed with winterfat individuals (with crown diameters less than $0.5 \mathrm{~m}$ and greater than $0.1 \mathrm{~m}$ ) as a corner starting point, and were visually aligned to maintain homogeneous vegetation of blue grama and winterfat. Several plots were identified in each position and of these 6 were randomly selected in the 2 positions (interior and peripheral) and 2 histories (grazed and ungrazed) within each community. The longest axis of rectangular peripheral plots was aligned perpendicular to, and across winterfat stand boundaries, identified by outlying winterfat plants.

Plants in each plot were subjected to 1 of 3 defoliation treatments. One defoliation treatment involved clipping all forage (grass, forbs, and shrubs, except yucca, cacti, and broom snakeweed) in June 1992, August 1992, June 1993, and June 1994. Grasses and forbs were clipped to a $2.5-\mathrm{cm}$ stubble height; shrub 
clipping removed one-half of all externally accessible crown growth. A browse-only treatment defoliated only shrubs in the same way as in the forage treatment in 1992, except that shrubs were subsequently defoliated in September in 1993, and 1994. Plants in control plots were not clipped. Clipping treatments were randomly assigned to 2 plots within each community position, at each location. Thus each combination of grazing history, community position and defoliation treatments was imposed on 2 plots in 3 stands.

\section{Winterfat Data Collection}

Winterfat plants in plots and individuals with canopy overhanging plots were measured for basal stem circumference, height, and 2 crown diameters. For plants outside of plots but with overhanging canopy, the percent of canopy that extended over the plot area was visually estimated on each sampling date so that canopy volume calculations included only canopy portions actually above the plot area. Percent cover was also estimated for plants rooted in the plot when the canopy extended outside the plot. Winterfat plants with canopies overlapping and intermixed with neighboring plant canopies were measured collectively and the canopy volume was divided equally among the number of individuals measured together. In this way, measurement of all canopy volume above the plot area could be calculated as well as volume for individual plants. Also, canopy volume over the plot area was separated into volume attributed to plants rooted in the plot and additional volume from overhanging plants not rooted in the plot.

Winterfat canopy volume was calculated by unit area (per plot basis) and for individuals (per plant basis). Individual plant canopy volume was calculated by dividing plot canopy volume sums by plot densities, after excluding overhanging canopy from plants not rooted in the plots. Winterfat canopy volume was calculated as one-half of a spheroid, comparable to Ludwig et al. (1975) for broom snakeweed. Thus, canopy volume of half of a spheroid $=4 / 3 \pi r^{2} h$, where $h$ is plant height and $r$ is average canopy radius. The average radius was derived by adding the maximum diameter and the diameter perpendicular to the maximum and dividing the sum by 4 . Mature winterfat plants were monitored to determine crown volume in June of 1992, 1993, and 1994. Initial data were collected prior to application of defoliation treatments.

\section{Data Analysis}

Data were analyzed as a split split-plot analysis of variance of a randomized block design. Main plots were locations with different grazing histories (Whittington Center or adjacent lands); subplots were interior or peripheral positions. Sub-sub plots were 3 defoliation treatments randomly assigned to 2 plots (samples) within each location and position in each community. Sampling dates were included as repeated measures. The study was established on areas separated by fence lines, each side of which had different past grazing histories. Thus, it was not possible to randomly assign grazing history to plots. Grazing history (location) treatment comparisons apply to the specific plots under study (Wester 1992).

Data were tested for conformance to assumptions of normality (Shapiro and Wilk 1965) and sphericity (homogeneous variances of differences between treatments, Mauchley 1940). When sphericity assumptions were violated, F-test degrees of freedom

\section{a. Defoliation}

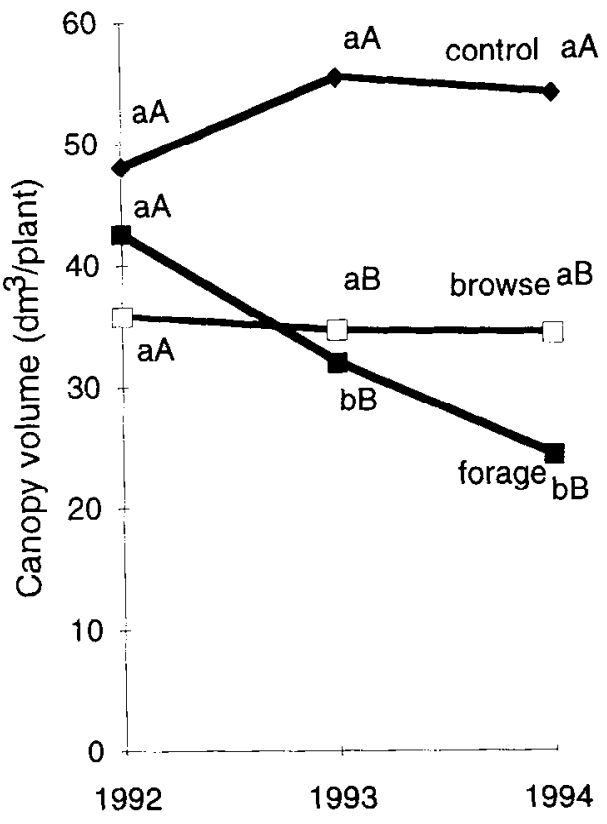

b. Position

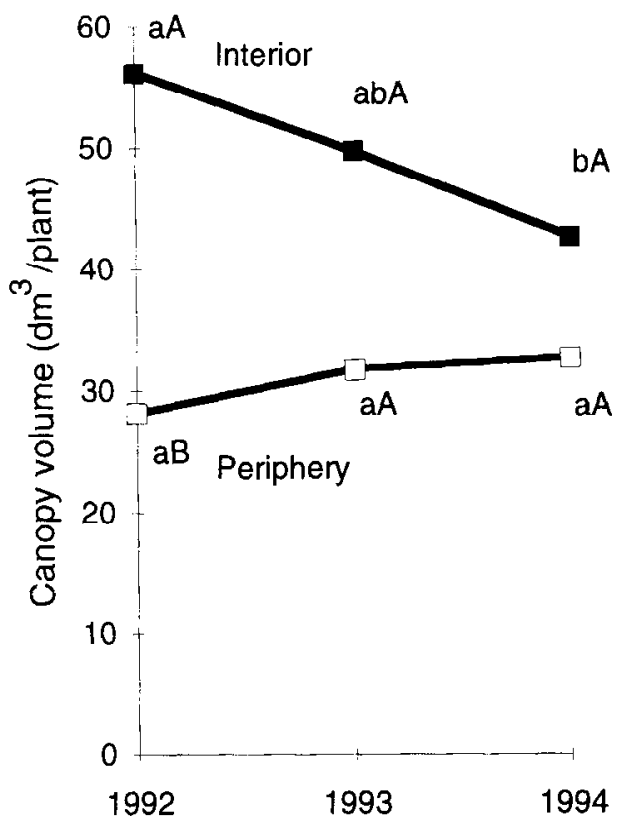

Fig. 2. Winterfat canopy volume per plant by defoliation treatment and year (a) and by position and year (b). Means within a treatment with the same lower tase letter do not differ; means within a year with the same upper case letter do not differ $(P>0.05$, LSD).

were adjusted using Greenhouse-Geisser estimates of the degree of violation (Geisser and Greenhouse 1958.) When 3-way and higher order treatment interactions occurred, F-tests were completed on interacting treatments within one level of the third interacting treatment, using error terms specific to the contrast, based 
on recommendations by Milliken and Johnson (1984). Mean separation was completed with protected Least Significant Differences (FLSD) also using error terms specific to the contrast.

\section{Results}

\section{Treatment Effects on a Per Plant Basis}

Winterfat canopy volume per plant differed among defoliation treatments and between community positions, and these differences depended on sampling date. At the beginning of the study, canopy volume of winterfat plants was similar in all 3 defoliation treatments (Fig. 2a). Canopy volume did not change in control or browse-only defoliated plots. Canopy volume decreased by 1993 when both herbaceous and browse plants were defoliated (forage treatment). In 1994, winterfat canopy volume was lower in defoliated plots (regardless of the type of defoliation) than in control plots.

Despite the foregoing effects, defoliation treatments did not interact with grazing history or community position effects. Thus, regardless of defoliation treatment effects, canopy volume of winterfat plants was greater in interior than in peripheral positions at the beginning of the study. However, while canopy volume remained stable in peripheral positions, canopy volume of winterfat plants on the interior positions decreased between 1992 and 1994 (Fig. 2b). This difference in response to defoliation resulted in equality of canopy volume between positions by 1993. It is assumed that the majority of decrease in canopy volume of individual plants resulted from defoliation. Since crown measures were recorded prior to defoliation, these results reflect recovery of plants from defoliation in the previous growing season.

\section{Treatment Effects on a Per Plot Basis}

Although winterfat canopy volume per plot was initially similar among defoliation treatments, canopy volume differed among

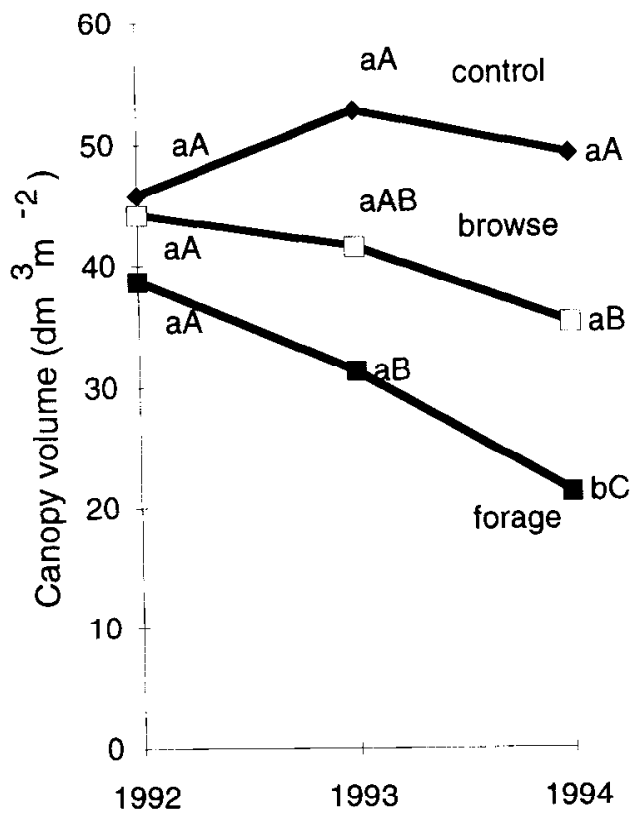

Fig. 3. Winterfat canopy volume per plot by defoliation treatment and year. Means within a treatment with the same lower case letter do not differ; means within a year with the same upper case letter do not differ $(P>0.05$, LSD).

\section{a. Ungrazed}

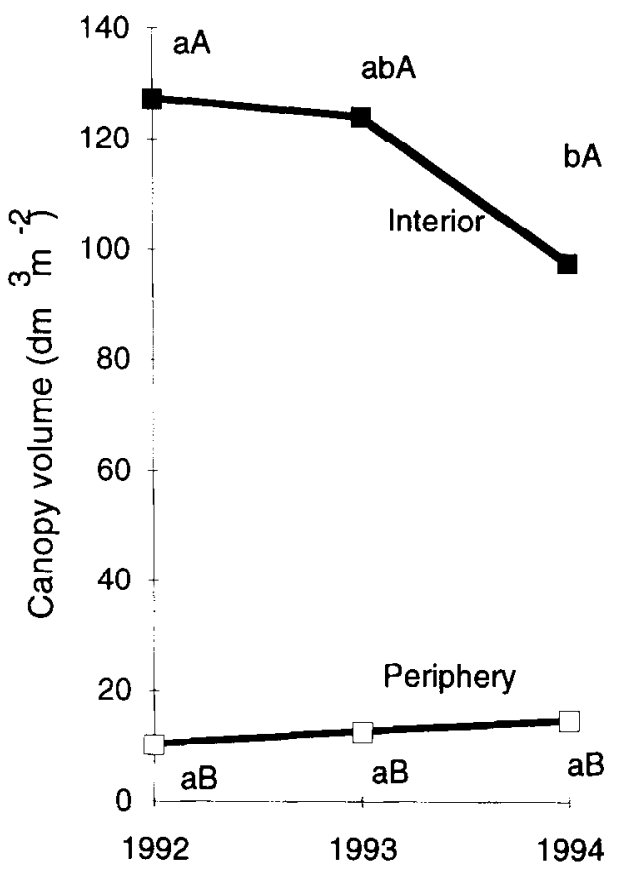

\section{b. Grazed}

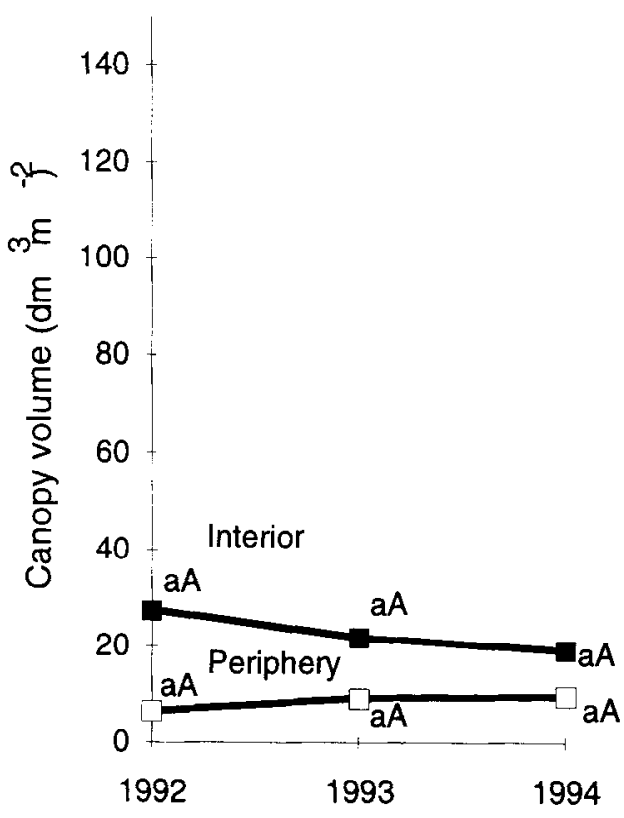

Fig. 4. Winterfat canopy volume per plot at ungrazed (a) and grazed (b) locations by position and year. Within each location, means within a position with the same lower case letter do not differ; means within a year with the same upper case letter do not differ $(\mathrm{P}>\mathbf{0 . 0 5}$, LSD).

defoliation treatments in 1993 and 1994 (Fig. 3). Canopy volume did not change in control plots during the study. Defoliation of forage plants decreased canopy volume by 1994 more than defoliation of only browse plants. After 3 years, canopy volume was 
greater in control plots than in defoliated plots. Additionally, forage-defoliated plots had lower canopy volume than browse-unly defoliated plots. These results were independent of location and position effects.

In addition to defoliation effects, winterfat canopy volume on a per plot basis was affected by position and grazing history. In ungrazed locations, canopy volume of plots in interior positions exceeded that of plots in peripheral positions (Fig. 4a). Although winterfat canopy volume of plots in ungrazed peripheral positions remained constant throughout the study period, winterfat canopy volume decreased in plots in interior positions from 1993 to 1994. In contrast, interior and peripheral plots had similar winterfat canopy volume in grazed locations, and winterfat canopy volume remained constant throughout the study period (Fig. 4b). Similarly, interior plots had winterfat canopy volume at ungrazed locations that exceeded winterfat canopy volume of plots in interior positions at grazed locations (Fig 5a). Although winterfat canopy volume at grazed locations remained constant during the study, winterfat canopy volume decreased at ungrazed plots between 1993 and1994. Finally, winterfat canopy volume per plot was similar and stable at ungrazed and grazed peripheries during the study period (Fig. 5b).

\section{Discussion}

\section{Trends from 2 Methods of Observation}

Interpretational differences exist between winterfat results measured on an individual plant basis or an area basis. A more complete understanding of winterfat dynamics is possible when these 2 methods of observation are synthesized.

\section{Mathematical Concerns and the Influence of Plant Density}

There are 2 potential sources of differences between per plant and per plot results for canopy volume that are a consequence of the mathematical calculations of the 2 methods. Per plot results included canopy of overhanging plants not rooted in the plot that are not part of per plant canopy results. Addition of non-rooted, overhanging plant canopy to per plot results could be a potential source of differences between thesc 2 data sets. However, in a separate analysis of non-rooted, overhanging canopy volume, this portion of per plot canopy volume did not alter treatment effects. Thus, differences between the 2 levels of observation derive from other sources.

Another source of discrepancy between per plant and per plot results stems from different plant density among treatments. In this study, winterfat density was greater in interior than in peripheral positions (22.2 and 5.0 plants per plot, respectively), since winterfat provided the basis for plot layout. Additionally, winterfat density at ungrazed interiors and peripheries was 32.3 and 2.4 plants per plot, respectively, and at grazed locations density was 12.0 and 7.5 plants per plot, respectively. The mathematical effect of density derives from obtaining per plant results by dividing per plot sums by plant density. If treatments differ in density, treatment effects that are significant for per plot results may not be significant in per plant results. This effect likely involves density-dependent relationships beyond the scope of this study, additionally, areas with different densities of winterfat may respond differently than our plots.

One example of differing per plot and per plant results due to
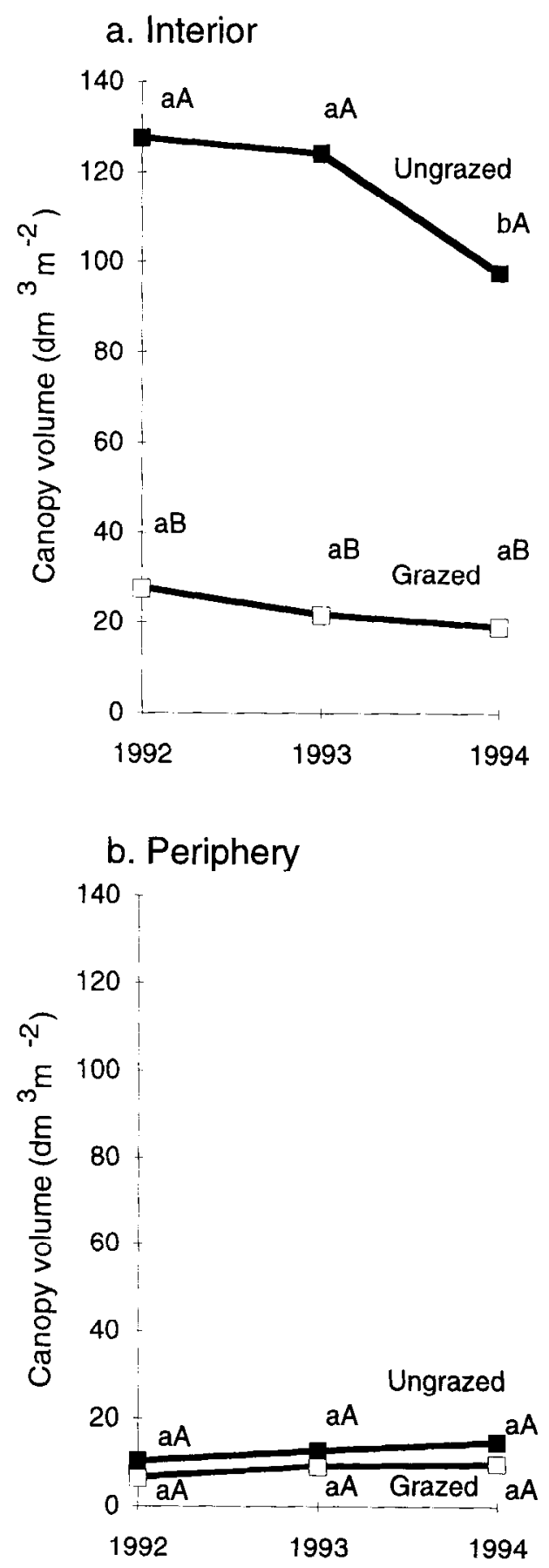

Fig. 5. Winterfat canopy volume per plot in interior (a) and periphery (b) positions by location and year. Within each position, means within a location with the same lower case letter do not differ; means within a year with the same upper case letter do not differ (P > 0.05, LSD).

mathematical influence of density is found in location effects. Winterfat canopy volume per plot in ungrazed interiors was greater than in ungrazed peripheries, grazed interiors, or grazed peripheries (Figs. 4, 5). However, individual winterfat plant results show no effect of location on canopy volume, and interior plants have greater canopy volume in the first year (1992) than 
periphery plants (Fig. 2b). Because there is a slight difference in density between the 2 locations, greater canopy volume of Whittington plots is divided by greater numbers of plants and thus the canopy volume per plant is equal to canopy volume per plant at adjacent locations. Since the effect of location on canopy volume is no longer significant at the per plant level, the effect of location for per plot results is derived from the difference in winterfat density of the 2 locations, and the per plant results indicate that the average canopy size of individual plants does not differ between locations.

\section{Biological Interpretation and Synthesis of Both Approaches}

Density has biological implications for both unit area and individual-based results. Greater density can cause biological effects related to greater canopy volume and cover per unit area. Greater density also provides the ecological context within which plant individuals are found. For example, individual plants in interiors are surrounded by more winterfat plants than are individuals at the periphery. In general, individual winterfat plants found on the ungrazed interior plots in 1992 (prior to defoliation) had smaller canopies when growing in plots with high densities than did winterfat plants growing in plots with lower density (Hild 1995). The biological impact of density on winterfat must be incorporated into both plant and plot results to describe meaningful trends. Density-dependent impacts on plant growth are common in plant ecology (Harper 1977). Biological impacts of density and plant size may include assessment of shade and interference competition, exploitation competition, and protection from wind.

The importance of measurement techniques is apparent. Both results (per plant and per plot) accurately describe winterfat canopy volume. Interpretations vary depending on the method of observation.

\section{Literature Cited}

Bonham, C.D. 1989. Measurements for terrestrial vegetation. John Wiley and Sons. New York, N.Y. 338 p.

Bryant, F.C. 1979. Variability in predicting edible browse from crown volume. J. Range Manage. 32:144-146.

Canfield, R.H. 1941. Application of the line interception method in sampling range vegetation. J. of Forestry. 39:388-394

Cook, C.W. and J. Stubbendieck (eds.) 1986. Range research: basic problems and techniques. Soc. for Range Manage. Denver, Colo. $317 \mathrm{p}$.

Daubenmire, R.F. 1968. Plant communities: a textbook of synecology. Harper and Row. New York. $300 \mathrm{p}$.

Geisser, S. and S.W. Greenhouse. 1958. An extension of Box's results on the use of the $\mathrm{F}$ distribution in multivariate analysis. Annals of Mathematical Statistics. 29:885-891.

Harper, J.L. 1977. Population biology of plants. Academic Press. London. $892 \mathrm{p}$.

Heady, H.F., R.P. Gibbens, and R.W. Powell. 1959. A comparison of the charting, line intercept, and linc point methods of sampling shrub types of vegetation. J. Range Manage. 12:180-188.

Hild, A.L. 1995. Winterfat-blue grama community ecotones under defoliation and removal of domestic herbivory. Texas Tech University, Lubbock. Ph.D. Diss.

Jameson, D.A. 1987. Monitoring for successful management. In: Monitoring animal performance and production, Symposium proceedings. Society for Range Management. Boise, Ida. 1-3.

Ludwig, J.A., J.F. Reynulds, and P.D. Whitson. 1975. Size-biomass relationships of several Chihuahuan Desert shrubs. Amer. Mid. Nat. $94: 451-461$.

Mauchley, J.W. 1940. Significance test for sphericity of a normal nvariate distribution. Annals of Mathematical Statistics. 11:204-209.
Milliken, G.A. and D.E. Johnson. 1984. Analysis of messy data, vol. 1: designed experiments. Van Nostrand Reinhold Co. N.Y. 473 p.

Morris, M.J., K.L. Johnson, and D.L. Neal. 1976. Sampling shrub ranges with an electronic capacitance instrument. J. Range Manage. 29:78-81.

Shapiro, S.S. and M.B. Wilk. 1965. An analysis of variance test for normality (complete samples). Biometrika. 52:591-611.

Taylor, J.E. 1986. Cover data in monitoring rangeland vegetation. In: Use of cover, soil and weather data in rangeland monitoring, Symposium proceedings, Kissimmee, Fla. Society for Range Manage. $15-24$.

USDA, SCS, and USFS. 1982. Soil survey of Colfax County, New Mexico. U.S. Government Printing Office. Washington D.C. 187 p.

Wester, D.B. 1992. Viewpoint: replication, randomization, and statistics in range research. J. Range Manage. 45:285-290.

Zamora, B.A. 1981. An approach to plot sampling for canopy volume in shrub communities. J. Range Manage. 34:155-156. 